\title{
Protection of Hawks and Eagles
}

\section{By Morris Jackson Reprinted from the Victoria Naturalist}

To furnish adequate rather than paper protection to hawks and eagles whom must we convince that such protection is necessary or justifiable? who ccmprise the hawk's presentday human enemies; with whom does the conservationist have to contend? There is the ammunition salesman who urges us to "kill triat pest", with his company's 'ammunition of course. I fear we can do little there. There is the poultryman, a very minor threat in himself where hawks are not actually preying on his stock. He is far too busy to go looking for hawks, and yet he has plenty of sympathisers to take up his cudgels and kill an csprey or black vulture (I have had both these birds described to me as a "great big hen-hawk".)

There is the youth, idle when school is out, who, whatever he may have learned there, has learned nothing of his debt to nature, of his kinship to creation. He wanders aimlessly, shooting with his .22 at any acceptable living target, and songbirds are "acceptable" they eat cherrics and damage gardens, though not his garden-he knows nothing of gardens. If he shoots a hawk he glows with civic pride. The law encourages him in this. Hawks kill birds. How many are there of these lads? Outside of the towns, they are legion. They have licenses, and if questioned are "hunting crows". It is true that they are required to be accompanied by an adult when shooting but they seldom are, and the adult is too often simply a youth over 18 years. How can we talk of hawk conservation to a killer of songbirds?

The adult sportsman is most unlikely to be a hawk conservationist. He usually subscribes to at least one magazine which relies on its sporting gocds advertisements. To such magazines every predator is "a killer" which must be put to death in the the interest of game conservation . . how often have we heard (these sportsmen) talk of a bird they have seen as a "great big hawk, or it may have been an eagle". Surely. Or a black vulture or heron . . . most certainly none of them know one hawk from another. And unless I held it in my hand, for the most part neither do I. It is imperative therefore that protection should include all hawks; a law that excludes accipiters gives no protection to any. One of the points raised by the Game Commissioner when I wrote about the necessity of protecting bald eagles was that it is easy to confuse their young with those of the Golden Eagle. I feel that both species should be protected.

\section{Do You Know the Hawks?}

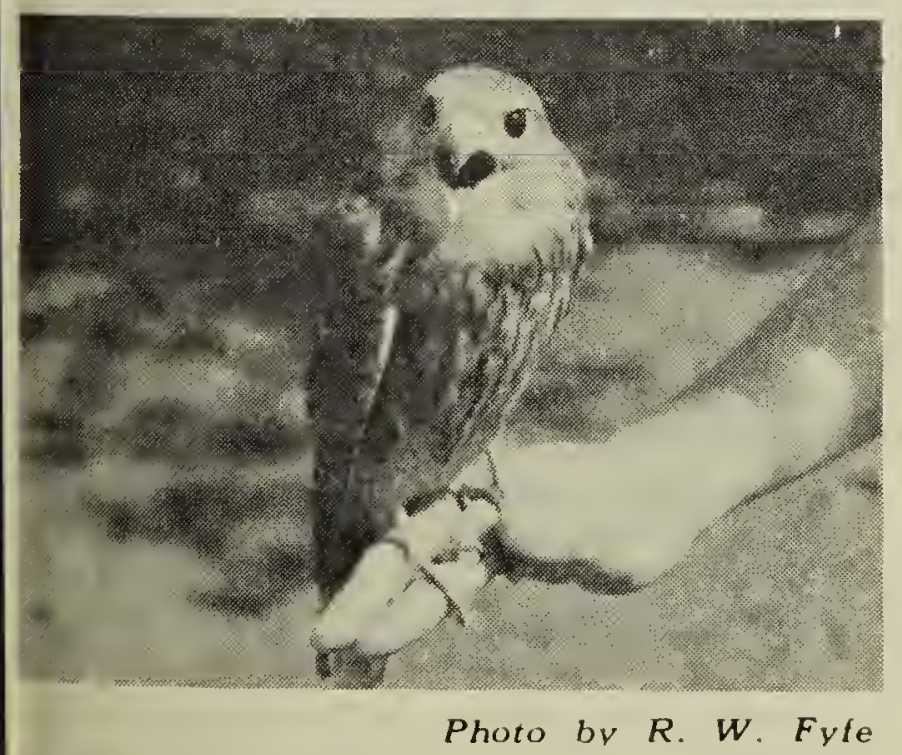

The young falcon in the picture is an immature male Richardson's Merlin. It was taken from a nest of four birds 17 miles west of Kinder- sley, Sask. on July 2, 1957. The young hawk is being raised by $R$. W. Fyfe, extension officer at the Museum, who wants to have people learn more about hawks and their role in nature. Perhaps hawks are the most misunderstood of all birds. In Saskatchewan at present five species of hawks are not protected-the Goshawk, Pigeon Hawk (of which the Richardson's Merlin is the western sub-species), Duck Hawk, Cooper's Hawk, Sharp-shinned Hawk. Two of the e species, the Duck Hawk and the Pidgeon Hawk, have recently received protection in British Columbia although Goshawks, Cooper's Hawks and sharp-shinned Hawks are still r.ot protected there. Should our society urge the full protection of birds of prey in Saskatchewan? 